\title{
Multiscale entropy analysis of wind speed dynamics in Petrolina, Northeast Brazil
}

\author{
Analise da dinâmica do vento em Petrolina, Nordeste do Brasil, utilizando Multiscale Entropy \\ Análisis de la dinámica del viento en Petrolina, Noreste de Brasil, utilizando Multiscale Entropy
}

Received: 12/23/2020 | Reviewed: 12/29/2020 | Accept: 12/30/2020 | Published: 01/03/2021

\author{
Gutenberg Ferreira da Silva \\ ORCID: https://orcid.org/0000-0002-7121-9953 \\ Federal Rural University of Pernambuco, Brazil \\ E-mail: gutenbergfs9@gmail.com \\ Íkaro Daniel de Carvalho Barreto \\ ORCID: https://orcid.org/0000-0001-7253-806X \\ Federal Rural University of Pernambuco, Brazil \\ E-mail: daniel.carvalho.ib@gmail.com \\ Tatijana Stosic \\ ORCID: https://orcid.org/0000-0002-5691-945X \\ Federal Rural University of Pernambuco, Brazil \\ E-mail: tastosic@gmail.com
}

\begin{abstract}
Purpose: In this paper, we analyzed the intra-annual variability of complexity of wind dynamics in Petrolina, Brazil and its relation with the wind potential. Methodology: We applied the Multiscale Sample Entropy (MSE) method on wind speed temporal series for each month of 2010. The data are recorded every $10 \mathrm{~min}$ at $50 \mathrm{~m}$ height. Results: The results showed higher entropy values at higher temporal scales indicating that wind speed fluctuations are les regular and less predictable when wind speed is observed at lower temporal frequency. For all months, average wind speed is above a cut in level $3.5 \mathrm{~ms}^{-1}$, the speed at which turbines start operating and producing electricity, indicating that the location of Petrolina is promising for wind energy generation. We also found that the wind speed is positively correlated with entropy values for all months when recorded at 10min frequency and between August and December when recorded $t$ $1 \mathrm{~h}$ frequency. Conclusion: In these periods wind speed temporal fluctuations are more irregular, which is considered as unfavorable condition for the operation of wind turbines, leading to lower efficiency in the capture of wind energy for electricity production.
\end{abstract}

Keywords: Wind speed; Multiscale entropy; Wind energy.

\section{Resumo}

Objetivo: Neste artigo analisamos a variabilidade intra-anual da complexidade da dinâmica do vento em Petrolina, Brasil e sua relação com o potencial eólico. Metodologia: Aplicamos o método Multiscale Sample Entropy (MSE) nas séries temporais da velocidade do vento para cada mês de 2010. Os dados são registrados a cada 10 minutos a 50m de altura. Resultados: Os resultados mostraram os valores de entropia mais altos em escales temporais maiores, indicando que as flutuações da velocidade do vento são menos regulares e menos previsíveis quando a velocidade do vento é observada em frequência temporal mais baixa. Em todos os meses a velocidade média do vento está acima de $3,5 \mathrm{~ms}{ }^{-1}$, velocidade na qual as turbinas começam a operar e produzir eletricidade, indicando que a localização de Petrolina é promissora para a geração de energia eólica. Também descobrimos que a velocidade do vento está positivamente correlacionada com os valores de entropia para todos os meses quando dados são registrados na freqüência de $10 \mathrm{~min}$ e entre agosto e dezembro quando são registrados na freqüência de $1 \mathrm{~h}$. Conclusão: Nestes períodos as flutuações temporais da velocidade do vento são mais irregulares, o que é considerado condição desfavorável para o funcionamento dos aerogeradores, levando a uma menor eficiência na captação de energia eólica para a produção de eletricidade.

Palavras-chave: Velocidade do vento; Multiscale entropy; Energia eólica.

\section{Resumen}

Objetivó: En este trabajo analizamos la variabilidad intra-anual de la complejidad de la dinámica del viento en Petrolina, Brasil y su relación con el potencial eólico. Metodología: Se aplicó el método de Multiscale Sample Entropy Entropy (MSE) en series temporales de velocidad del viento para cada mes de 2010. Los datos se registran cada 10 min a $50 \mathrm{~m}$ de altura. Resultados: Los resultados mostraron valores de entropía más altos en escalas temporales más altos, lo que indica que las fluctuaciones de la velocidad del viento son menos regulares y menos predecibles cuando la velocidad del viento se observa a una frecuencia temporal más baja. Para todos los meses, la velocidad media del viento está por encima de $3.5 \mathrm{~ms}^{-1}$, la velocidad a la que las turbinas comienzan a funcionar y a producir electricidad, lo que indica que la ubicación de Petrolina es prometedora para la generación de energía eólica. También encontramos que la velocidad del viento se correlaciona positivamente con los valores de entropía para todos los meses cuando se registra a una frecuencia de 10 min y entre agosto y diciembre cuando se registra una frecuencia de $\mathrm{t} 1 \mathrm{~h}$. Conclusión: En estos 
períodos las fluctuaciones temporales de la velocidad del viento son más irregulares, lo que se considera una condición desfavorable para el funcionamiento de los aerogeneradores, lo que conlleva una menor eficiencia en la captación de energía eólica para la producción de electricidad.

Palabras clave: Velocidad del viento; Multiscale entropy; Energía eólica.

\section{Introduction}

Among renewable energy sources wind power is one with most rapidly growing rate over the last decades because of its high efficiency and low pollution. As a wind producer Brazil ranks in the sixth place in the world, behind China, USA, Germany, India and France. At the end of 2019 Brazilian production was $15.45 \mathrm{GW}$ representing $2.5 \%$ of the total worldwide onshore capacity(GWEC, 2019). It is projected to grow to $8.0 \%$, in 2020 , where half of the total capacity will be installed in the Northeastern region (Witzler, Ramos, Camargo, \& Guarnier, 2016). This remarkable growth is the result of the government Program for Incentive of Alternative Electric Energy Sources (Programa de Incentivo às Fontes Alternativas de Energia Elétrica - Proinfa), which was created in 2002 to stimulate the electricity generation from wind power, biomass, and small hydroelectric plants (Dutra \& Szklo, 2008). During the dry season in Northeast of Brazil, the temporal variation of the wind potential shows complementarity with the flows of the São Francisco river (Faria, Justino, \& Monteiro, 2011) and wind electricity generation is extremely important for electricity supply in this region which often experiences prolonged drought periods, when hydroelectric plants decrease the electricity production due to very low flows and reservoirs levels (Cavalcante, Vieira, Campos, Brandini, \& Medeiros, 2020). However, due to intermittency and high spatio-temporal variability of wind speed, large scale integration of wind power into electricity grid is still challenging task (Behera, Sahoo, \& Pati, 2015).

The evaluation of the wind potential at certain location requires a detailed statistical analysis of the wind speed and its frequency distribution at different heights and different periods during the year (de Araujo Lima \& Bezerra Filho, 2010; Tar, 2008). However, the knowledge of the temporal organization (complexity) of wind speed can provide valuable information about underlying stochastic processes that cannot be assessed through traditional statistical analysis. This knowledge is important for the planning of wind energy production and for evaluation of predictive models for wind speed and wind power.

During the last decades various concepts and methods were developed to analyze complexity of temporal series, among which fractal and multifractal methods, methods based on information theory and complex networks were used to analyze wind speed data from different parts of the world (Koçak, 2009; Laib, Golay, Telesca, \& Kanevski, 2018; Laib, Guignard, Kanevski, \& Telesca, 2019; Q. Li \& Zuntao, 2014). Among these methods, approaches that rely on entropy are particularly interesting due to their simplicity, lack of intensive computations, and robustness for short non-stationary and noisy data.

In this work we evaluate the complexity of wind speed dynamics using Multiscale Entropy method which provides information about time series regularity for multiple temporal scales (Costa, Goldberger, \& Peng, 2002). We analyze high frequency data recorded in the city of Petrolina, which is considered one of most promising locations for wind energy production in Pernambuco, Brazil (Silva et al, 2002).

\section{Methodology}

The present study is a quantitative research (Pereira, Shitsuka, Parreira, \& Shitsuka, 2018) that evaluates the complexity of wind speed dynamics using Multiscale Entropy method.

\subsection{Data}

The data used in this work are wind speed temporal series recorded at SONDA station (SONDA-Sistema Nacional de Organização de Dados Ambientais) in Petrolina, Brazil (09 04 '08 "S latitude, $40^{\circ}$ 19' 11 "O longitude, and altitude of 387m). The data was obtained from INPE- Instituto Nacional de Estudos Espaciais and are available at the electronic address 
<http://sonda.ccst.inpe.br/basedados/petrolina.html>. The series are composed of 10-minute observations recorded at height of $50 \mathrm{~m}$ in the year 2010 ( 52000 data points) as shown in Figure 1.

Figure 1. Original wind speed series recorded at the Petrolina station.
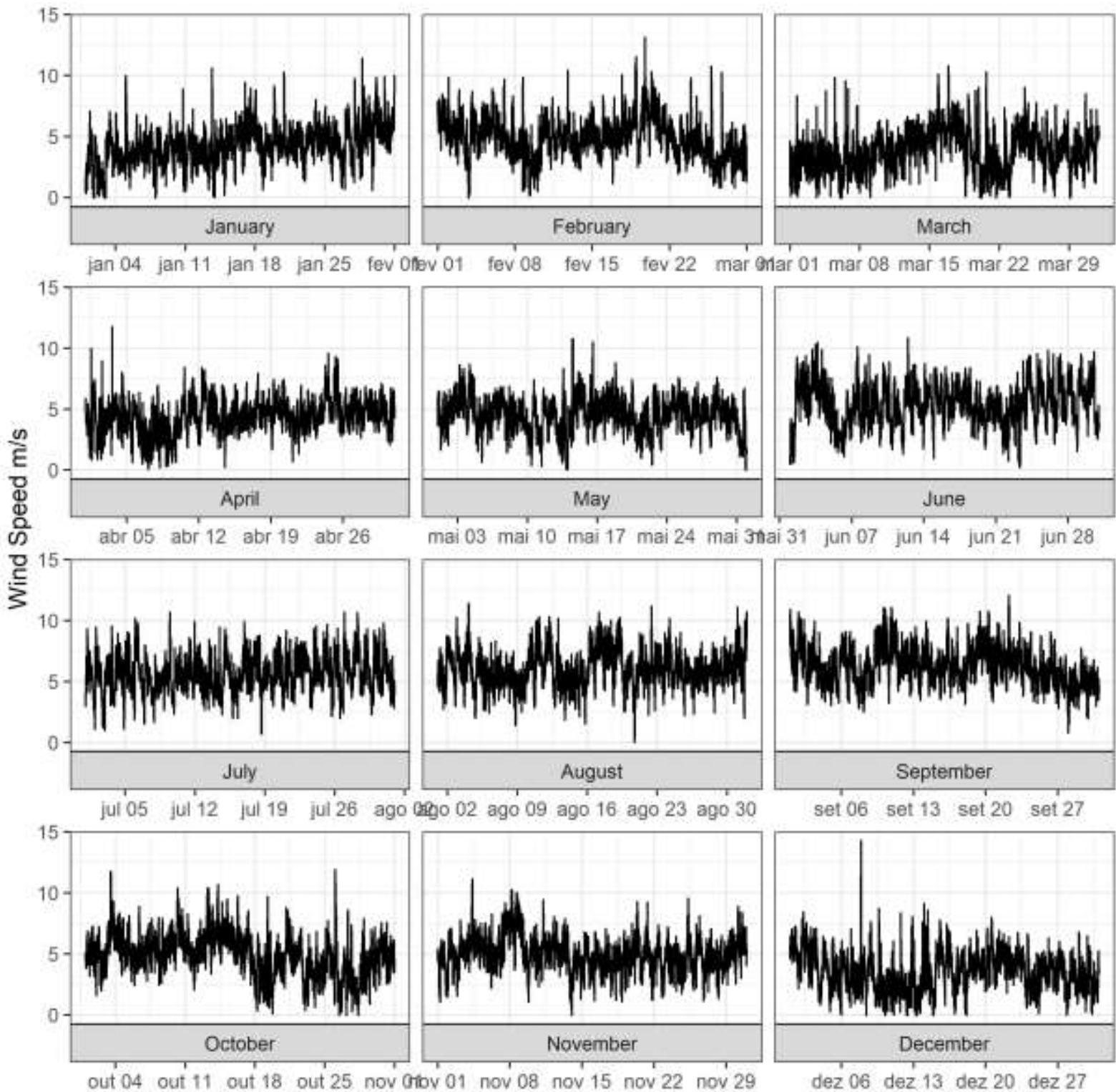

Note: Figure 1 shows wind speed $(\mathrm{m} / \mathrm{s})$ in each month of 2010 in Petrolina. Source: Author.

\subsection{Sample Entropy}

Sample entropy (SampEn) was introduced by Richman and Moorman, to evaluate the complexity of short non-stationary signals by examining time series for similar epochs, where more frequent and similar epochs (i.e., increased regularity in the time series) lead to lower values of SampEn, while less frequent and similar epochs (decreased regularity) lead to higher values of SampEn (Richman \& Moorman, 2000). SampEn $(m, r, N)$ is defined as the negative natural logarithm of the conditional probability that two sequences (of consecutive data within the time series) which are similar for $m$ points remain similar at the next point, where self-matches are not included. In calculating the probability.

Sample entropy algorithm is described as follows (Silva et al., 2002): 
i) For a time, series of length $N, u(j), j=1, \ldots, N$, we form $N-m+1$ vectors of length $m$, $x_{m}(i), i=1, \ldots, N-m+1$ where $x_{m}(i)=\{u(i+k): k=0, \ldots, m-1\}$

ii) The distance between vectors $x_{m}(i)$ and $x_{m}(j)$ is defined as

$$
d\left[x_{m}(i), x_{m}(j)\right]=\max \{|u(i+k)-u(j+k)|: k=0, \ldots, m-1\}
$$

iii) Next we count the number $B_{i}$ of vectors $x_{m}(j)$ such that $d\left[x_{m}(i), x_{m}(j)\right] \leq r$ where $r$ is a tolerance level ( $r \equiv r \sigma, \sigma$-standard deviation of $u(i), i=1, \ldots, N), j=1, \ldots, N-m$ and $j \neq i$ to exclude self-matches.

iv) We then define

$$
B_{i}^{m}(r)=\frac{B_{i}}{N-m-1} \text { and } B^{m}(r)=\frac{\sum_{i=1}^{N-m} B_{i}^{m}(r)}{N-m}
$$

where $B^{m}(r)$ is the probability that two vectors will match for $m$ points.

v) We repeat steps i-iv for vectors of length $m+1$ and count the number $A_{i}$ of vectors $x_{m+1}(j)$ which are within tolerance level $r$ of $x_{m+1}(i)$ and again we exclude self-matches. We define

$$
A_{i}^{m}(r)=\frac{A_{i}}{N-m-1} \text { and } A^{m}(r)=\frac{\sum_{i=1}^{N-m} A_{i}^{m}(r)}{N-m}
$$

where $A^{m}(r)$ is the probability that two vectors will match for $m+1$ points.

vi) Sample entropy (SampEn) is defined as

$$
S_{E}(m, r)=\lim _{N \rightarrow \infty}\left[-\ln \frac{A^{m}(r)}{B^{m}(r)}\right]
$$

which is estimated by the statistics

$$
S_{E}(m, r, N)=-\ln \frac{A^{m}(r)}{B^{m}(r)}
$$

Sample entropy method was used to analyze data in physiology, geophysics, engineering and hydrology (Balasis et al., 2009; Chou, 2014; Kumar, Pachori, \& Acharya, 2017; Ni, Feng, Wang, Yang, \& Wang, 2017; Santana, Stosic, Ferreira, \& Silva, 2020a, 2020b). 


\subsection{Multiscale Sample Entropy}

Multiscale sample entropy method (MSE) was introduced by Costa et al., as a generalization of Sample entropy method (Costa et al., 2002; Richman \& Moorman, 2000). MSE takes into account the multiple time scales by calculating sample entropy for consecutive coarse-grained time series $x^{\tau}(j), j=1, \ldots, N / \tau$ determined by the scale factor $\tau$ : $x^{\tau}(j)=\frac{1}{\tau} \sum_{i=(j-1) \tau+1}^{j \tau} x(i)$ where $x(i), i=1, \ldots, N$ is original time series. It was shown that uncorrelated signals (white noise) have, for larger scales $\tau$, lower MSE values then correlated noise, indicating that MSE is more efficient for quantifying complexity in short and noisy time series, then traditional entropy methods that evaluate pattern repetition on single temporal scale. MSE method was used in analyzing physiological signals, hydrological processes, geophysical signals, and financial time series (Courtiol et al., 2016; Gamboa, Marques, \& Stosic, 2019; Guzman-Vargas, Ramírez-Rojas, \& Angulo-Brown, 2008; Zhou, Zhang, Li, \& Chen, 2012).

\section{Results and Discussion}

The results of the descriptive statistics are presented in Table 1. For most wind turbines, the range of cut-in wind speed (the speed at which the turbine starts producing the energy) is 3.5-4.5 ms ${ }^{-1}$ (Ayodele \& Ogunjuyigbe, 2016). It is seen from Table 1 that the average wind speed is above cut in level during the whole year confirming that the location of Petrolina is promising for wind energy generation. The average wind speed is the highest (with lowest variation) in September indicating the most favorable period of year for energy generation.

Table 1. Descriptive statistics for wind speed $\left(\mathrm{ms}^{-1}\right)$ temporal series recorded in Petrolina during the year of 2010.

\begin{tabular}{llllll}
\hline Month & Average & Min & Max & SD & CV \\
\hline January & 4,26 & 0,00 & 11,40 & 1,56 & 0,37 \\
February & 4,88 & 0,00 & 13,13 & 1,65 & 0,34 \\
March & 3,82 & 0,00 & 10,77 & 1,67 & 0,44 \\
April & 4,38 & 0,09 & 11,73 & 1,37 & 0,31 \\
May & 4,55 & 0,01 & 10,76 & 1,36 & 0,30 \\
June & 5,35 & 0,00 & 10,82 & 1,73 & 0,32 \\
July & 5,64 & 0,67 & 10,65 & 1,50 & 0,26 \\
August & 5,96 & 0,01 & 11,38 & 1,51 & 0,25 \\
September & 6,27 & 0,78 & 12,04 & 1,52 & 0,24 \\
October & 4,96 & 0,00 & 11,91 & 1,74 & 0,35 \\
November & 4,94 & 0,00 & 11,15 & 1,44 & 0,29 \\
December & 3,62 & 0,00 & 14,30 & 1,64 & 0,45 \\
\hline
\end{tabular}

Legend: Min - Minimun. Max - Maximun. SD - Standard Deviation. CV - Coefficient of Variation. Note: Table 1 shows wind speed (m/s) descriptive statistics for each month of 2010 in Petrolina. Source: Authors.

Table 2 presents the MSE values for $\tau=1,2,3,4,5,6$ where $\tau=6$ corresponds to calculating averages of 10 min wind speed values for consecutive 1-hour periods. It is seen from Table 2 that MSE increases with scale $\tau$ indicating that wind dynamics is more irregular (less predictable) when observed on higher temporal scales. For most scales MSE values are lowest in October ( $\tau=2,3,4,6)$ and highest in May ( $\tau=3,4,5,6)$ indicating that the most regular (most predictable) wind regime at Petrolina location is in October while most irregular (least predictable) in May. For $\tau=1$ entropy value is the highest in September, month with the highest value of average speed. The power of the wind per unit area is given by $P(v)=\frac{1}{2} \rho v^{3}$, where $P\left(W m^{-2}\right)$ is the power per unit area, $\rho\left(\mathrm{kgm}^{-3}\right)$ is the air density, and $v\left(\mathrm{~ms}^{-1}\right)$ is the wind speed (Safari \& Gasore, 2010). Considering average wind speed September is the moth with the most favorable conditions for energy generation. However, the dynamical 
regularity of wind speed temporal series is the lowest in September (highest entropy values) which can be considered as the is unfavorable condition for the operation of wind turbines. In order to contribute to a better understanding of the intra-annual temporal variability of conditions for wind power generation in Petrolina, we analyzed the correlation between average wind speed and entropy values for each month.

Table 2. MSE values $(\mathrm{m}=2, \mathrm{r}=0,20, \tau=1,2,3,4,5,6)$ for wind speed temporal series recorded in Petrolina during the year 2010 .

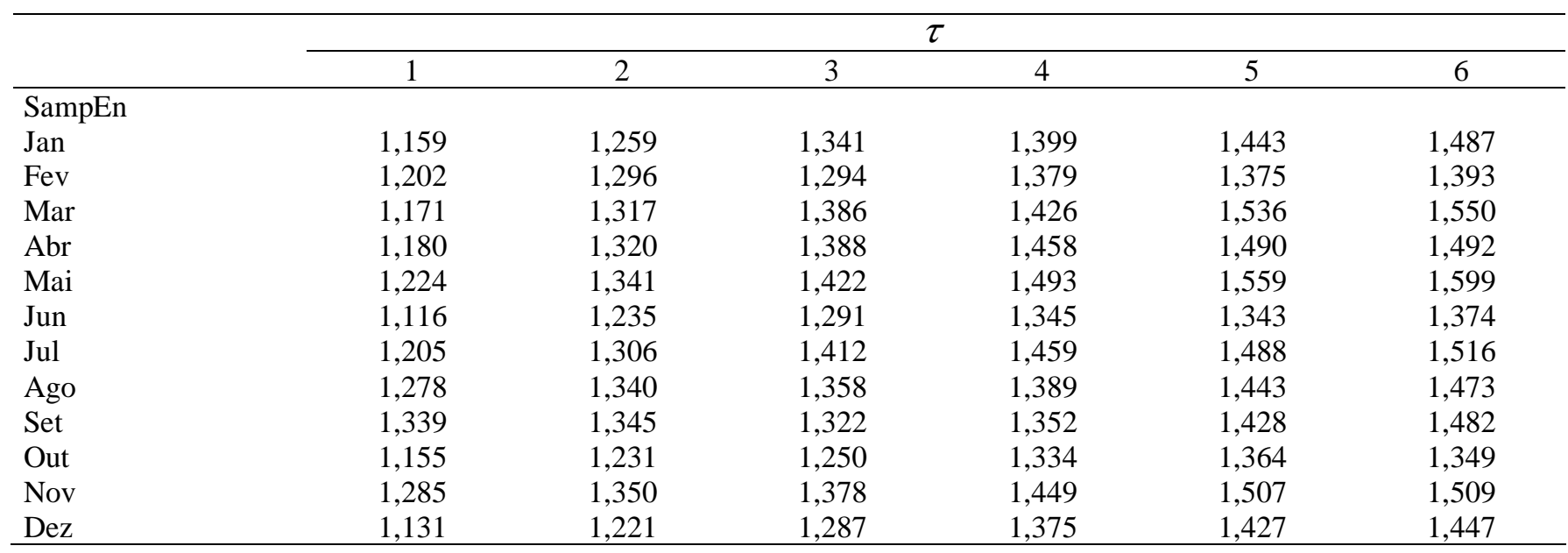

Note: Table 2 shows wind speed (m/s) MSE values for scales 1 to 6 for each month of 2010 in Petrolina. Source: Authors.

The results for $10 \mathrm{~min}$ frequency $(\tau=1)$ and 1-hour frequency $(\tau=6)$ are shown on figure 2 , where it can be observed that for $\tau=1$ wind speed and entropy are positively correlated (Pearson coefficient P-0.64), while for $\tau=6$ positive correlation is observed between August and December. Ahmed and Mandic analyzed vertical component and horizontal component (eastwest) of wind velocity temporal series recorded with 3D anemometer and also found the increase of entropy with wind speed (Ahmed \& Mandic, 2011). Li et al. 2011 analyzed the wind dynamics in the horizontal plane near the surface and also found that the entropy and wind speed are positively correlated (H. Li, Meng, Wang, \& Zeng, 2011). 
Figure 2. Intra annual variation of MSE values (together with average wind speed) for (a) $\tau=1$ and (b) $\tau=6$.

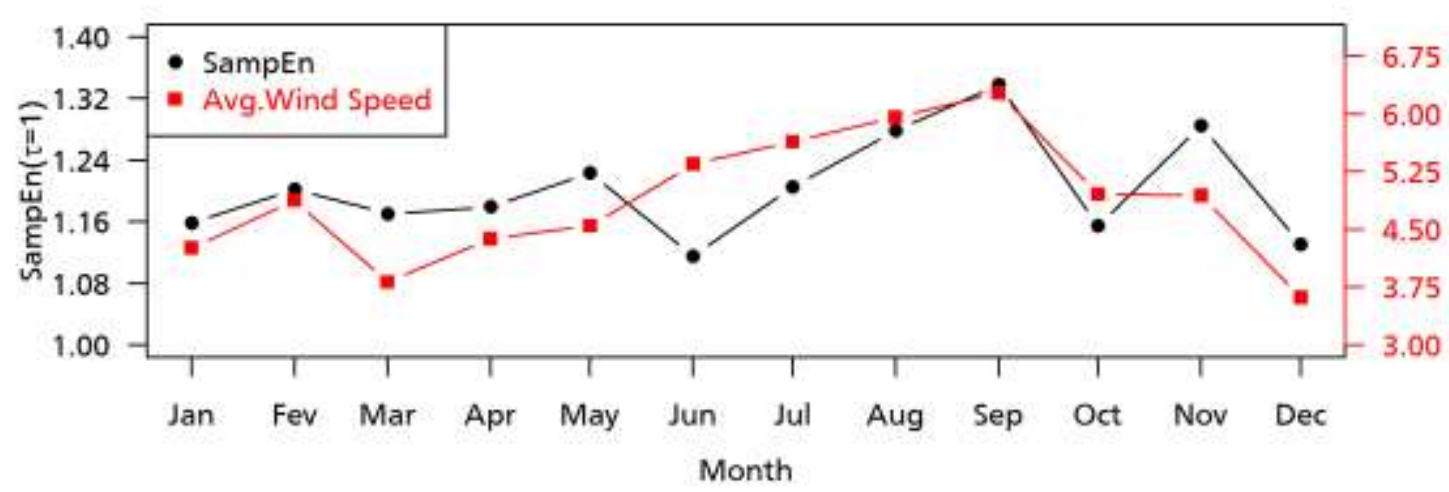

Pearson $P=0.64(p=0.025)$

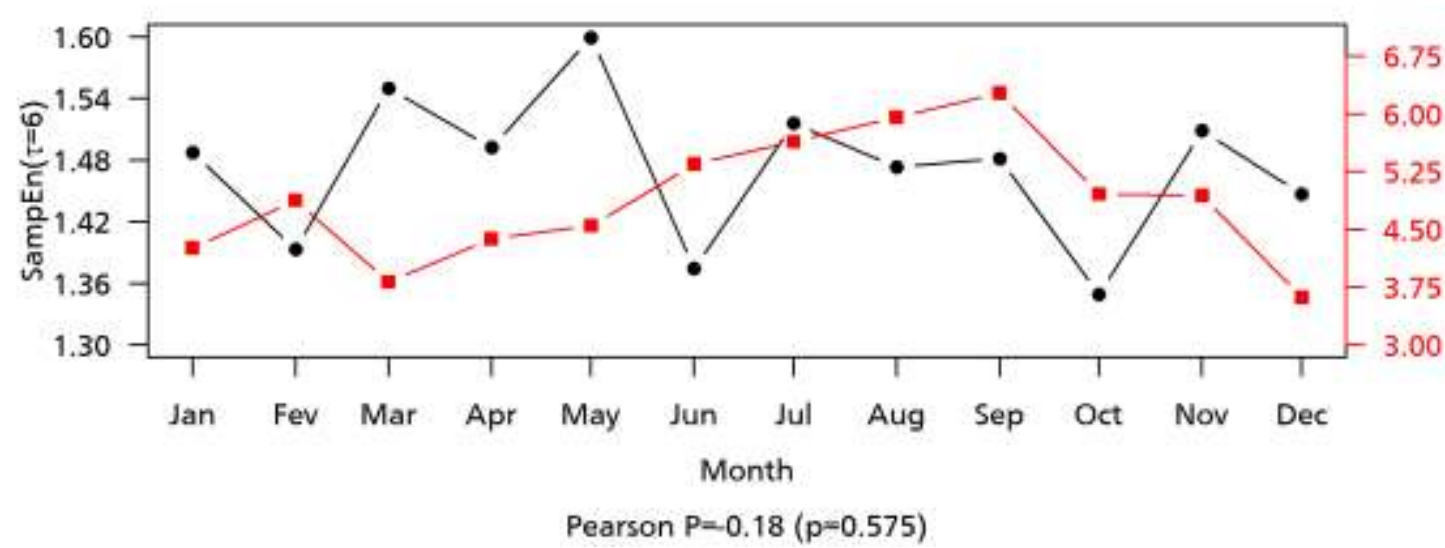

Note: Figure 2 shows wind speed (m/s) averages and MSE values for scales 1 and 6 for each month of 2010 in Petrolina and Pearson correlation. Source: Authors.

\section{Conclusions}

In this work, we studied intra annual complexity of the time series of wind speed in Petrolina using Multiscale Sample Entropy method (MSE). We found that the entropy values increase as the temporal scale increases, indicating les regular and less predictable wind speed series when recorded with lower temporal frequency.

Although for all month's average wind speed is above cut in level $3.5 \mathrm{~ms}^{-1}$ at which most turbines start to produce electricity, dynamical regularity of wind speed temporal series revealed by MSE analysis provides an additional valuable information: for $10 \mathrm{~min}$ frequency wind speed and entropy are positively correlated (Pearson coefficient P-0.64), while for 1hour positive correlation is observed between August and December. Higher entropy values indicate fewer regular dynamics, which is unfavorable condition for the operation of wind turbines and consequently there is less efficiency in the capture of wind energy for wind electricity production.

Future studies should be focused on large scale spatial analysis by including data from various locations that are considered as promising for wind power generation in Brazil.

\section{Acknowledgments}

The authors acknowledge support of Brazilian agency CNPq, through the following research grant: 304497/2019-3. 


\section{References}

Ahmed, M. U., \& Mandic, D. P. (2011). Multivariate multiscale entropy: A tool for complexity analysis of multichannel data. Physical Review E, 84(6), 61918. APS.

de Araujo Lima, L., \& Bezerra Filho, C. R. (2010). Wind energy assessment and wind farm simulation in Triunfo-Pernambuco, Brazil. Renewable Energy, 35(12), 2705-2713. Elsevier.

Ayodele, T. R., \& Ogunjuyigbe, A. S. O. (2016). Wind energy potential of Vesleskarvet and the feasibility of meeting the South African' s SANAE IV energy demand. Renewable and Sustainable Energy Reviews, 56, 226-234. Elsevier.

Balasis, G., Daglis, I. A., Papadimitriou, C., Kalimeri, M., Anastasiadis, A., \& Eftaxias, K. (2009). Investigating dynamical complexity in the magnetosphere using various entropy measures. Journal of Geophysical Research: Space Physics, 114(A9). Wiley Online Library.

Behera, S., Sahoo, S., \& Pati, B. B. (2015). A review on optimization algorithms and application to wind energy integration to grid. Renewable and Sustainable Energy Reviews, 48, 214-227. Elsevier.

Cavalcante, G., Vieira, F., Campos, E., Brandini, N., \& Medeiros, P. R. P. (2020). Temporal streamflow reduction and impact on the salt dynamics of the São Francisco River Estuary and adjacent coastal zone (NE/Brazil). Regional Studies in Marine Science, 38, 101363. Elsevier.

Chou, C.-M. (2014). Complexity analysis of rainfall and runoff time series based on sample entropy in different temporal scales. Stochastic Environmental Research and Risk Assessment, 28(6), 1401-1408. Springer.

Costa, M., Goldberger, A. L., \& Peng, C.-K. (2002). Multiscale entropy analysis of complex physiologic time series. Physical review letters, 89(6), 68102. APS.

Courtiol, J., Perdikis, D., Petkoski, S., Müller, V., Huys, R., Sleimen-Malkoun, R., \& Jirsa, V. K. (2016). The multiscale entropy: Guidelines for use and interpretation in brain signal analysis. Journal of neuroscience methods, 273, 175-190. Elsevier.

Dutra, R. M., \& Szklo, A. S. (2008). Incentive policies for promoting wind power production in Brazil: Scenarios for the Alternative Energy Sources Incentive Program (PROINFA) under the New Brazilian electric power sector regulation. Renewable Energy, 33(1), 65-76. Elsevier.

Faria, B. L. de, Justino, F. B., \& Monteiro, L. I. B. (2011). Estudo do Potencial Eólico do Nordeste Brasileiro: uma alternativa para complementar a Matriz Energética durante o período de seca. XVII Congresso Brasileiro de Agrometeorologia. https://silo.tips/download/estudo-do-potencial-eolico-do-nordestebrasileiro-uma-alternativa-para-complemen.

Gamboa, J. C. R., Marques, E. C. M., \& Stosic, T. (2019). Complexity analysis of Brazilian agriculture and energy market. Physica A: Statistical Mechanics and its Applications, 523, 933-941. Elsevier.

Guzman-Vargas, L., Ramírez-Rojas, A., \& Angulo-Brown, F. (2008). Multiscale entropy analysis of electroseismic time series. Natural Hazards and Earth System Sciences, 8(4), 855-860. Copernicus GmbH.

GWEC, G. W. E. C. (2019). Global Wind Report: Annual Market Update 2019. Retrieved March 6, 2020, from https://gwec.net/global-wind-report-2019

Koçak, K. (2009). Examination of persistence properties of wind speed records using detrended fluctuation analysis. Energy, 34(11), 1980-1985. Elsevier.

Kumar, M., Pachori, R. B., \& Acharya, U. R. (2017). Automated diagnosis of myocardial infarction ECG signals using sample entropy in flexible analytic wavelet transform framework. Entropy, 19(9), 488. Multidisciplinary Digital Publishing Institute.

Laib, M., Golay, J., Telesca, L., \& Kanevski, M. (2018). Multifractal analysis of the time series of daily means of wind speed in complex regions. Chaos, Solitons \& Fractals, 109, 118-127. Elsevier.

Laib, M., Guignard, F., Kanevski, M., \& Telesca, L. (2019). Community detection analysis in wind speed-monitoring systems using mutual information-based complex network. Chaos: An Interdisciplinary Journal of Nonlinear Science, 29(4), 43107. AIP Publishing LLC.

Li, H., Meng, Q., Wang, Y., \& Zeng, M. (2011). Multi-scale entropy analysis of single-point wind speed in outdoor near-surface environments. 2011 International Conference on Electrical and Control Engineering (pp. 4579-4582). IEEE.

Li, Q., \& Zuntao, F. (2014). Permutation entropy and statistical complexity quantifier of nonstationarity effect in the vertical velocity records. Physical Review E, 89(1), 12905. APS.

Ni, Q., Feng, K., Wang, K., Yang, B., \& Wang, Y. (2017). A case study of sample entropy analysis to the fault detection of be aring in wind turbine. Case studies in engineering failure analysis, 9, 99-111. Elsevier.

Pereira, A. S., Shitsuka, D. M., Parreira, F. J., \& Shitsuka, R. (2018). Metodologia da pesquisa científica Santa Maria, Brazil. https://repositorio.ufsm.br/bitstream/handle/1/15824/Lic_Computacao_Metodologia-Pesquisa-Cientifica.pdf?sequence=1

Richman, J. S., \& Moorman, J. R. (2000). Physiological time-series analysis using approximate entropy and sample entropy. American Journal of PhysiologyHeart and Circulatory Physiology, 278(6), H2039-H2049. American Physiological Society Bethesda, MD.

Safari, B., \& Gasore, J. (2010). A statistical investigation of wind characteristics and wind energy potential based on the Weibull and Rayleigh models in Rwanda. Renewable Energy, 35(12), 2874-2880. Elsevier.

Santana, L. V. R., Stosic, T., Ferreira, T. A. E., \& Silva, A. S. A. da. (2020a). Comparação dos dados da velocidade do vento no Nordeste do Brasil da ERA-40 e Instituto Nacional de Meteorologia (INMET) utilizando medidas de entropia. Research, Society and Development, 9(8), e446985257. https://rsdjournal.org/index.php/rsd/article/view/5257 
Research, Society and Development, v. 10, n. 1, e8210111460, 2021

(CC BY 4.0) | ISSN 2525-3409 | DOI: http://dx.doi.org/10.33448/rsd-v10i1.11460

Santana, L. V. R., Stosic, T., Ferreira, T. A. E., \& Silva, A. S. A. da. (2020b). Análise da regularidade da velocidade do vento no Nordeste do Brasil através da Sample Entropy. Research, Society and Development, 9(7), e762974746. https://rsdjournal.org/index.php/rsd/article/view/4746

Silva, B. B. da, Alves, J. J. A., Cavalcanti, E. P., \& Dantas, R. T. (2002). Potencial eólico na direção predominante do vento no Nordeste brasileiro. Revista Brasileira de Engenharia Agrícola e Ambiental, 6(3), 431-439. SciELO Brasil.

Tar, K. (2008). Some statistical characteristics of monthly average wind speed at various heights. Renewable and Sustainable Energy Reviews, 12(6), 17121724. Elsevier.

Witzler, L. T., Ramos, D. S., Camargo, L. A. S., \& Guarnier, E. (2016). Reconstruction of wind generation historical series aiming at the analysis of energy complementarity: Methodology and applications. 2016 13th International Conference on the European Energy Market (EEM) (pp. 1-6). IEEE.

Zhou, Y., Zhang, Q., Li, K., \& Chen, X. (2012). Hydrological effects of water reservoirs on hydrological processes in the East River (China) basin: complexity evaluations based on the multi-scale entropy analysis. Hydrological Processes, 26(21), 3253-3262. Wiley Online Library. 